\title{
Susceptibility of hepatoma-derived cells to histone deacetylase inhibitors is associated with ID2 expression
}

\author{
RYOUICHI TSUNEDOMI ${ }^{1}$, NORIO IIZUKA ${ }^{2}$, SAWAKO HARADA $^{1}$ and MASAAKI OKA ${ }^{1}$ \\ Departments of ${ }^{1}$ Digestive Surgery and Surgical Oncology and ${ }^{2}$ Complementary Medicine, \\ Yamaguchi University Graduate School of Medicine, Ube, Yamaguchi 755-8505, Japan
}

Received October 15, 2012; Accepted December 5, 2012

DOI: 10.3892/ijo.2013.1811

\begin{abstract}
Downregulation of inhibitor of DNA binding 2 (ID2) is associated with poor prognosis in cases of hepatocellular carcinoma (HCC). Therefore, to search for effective antitumor drugs for the treatment of $\mathrm{HCC}$ exhibiting poor prognostic indicators, we used two HCC-derived cell lines (HuH-7 and HLE) to alter ID2 levels. Specifically, ID2 expression was knocked down in HuH-7 cells via transfection with $I D 2$-specific small interfering RNAs and separately ID2 was overexpressed in HLE cells via an ID2 expression plasmid vector. To assess the effect of antitumor drugs, MTS assay was performed. Annexin V staining was used to evaluate apoptosis and real-time RT-PCR was used to measure mRNA levels. ID2 knockdown cells were more susceptible to histone deacethylase (HDAC) inhibitors including sodium butyrate $(\mathrm{NaB})$, sodium 4-phenyl-butyrate, tricostatin A, suberoylanilide hydroxamic acid, MS-275, apicidin and HC-toxin. Conversely, cells that overexpressed ID2 were less susceptible than control cells to HDAC inhibitors. NaB-induced apoptosis was inversely correlated with $I D 2$ expression. Expression of the anti-apoptotic mRNA $B C L 2$ was induced by $\mathrm{NaB}$ in control cells, but this induction of $B C L 2$ was inhibited by $I D 2$ knockdown and strengthened by $I D 2$ overexpression. Expression of another anti-apoptotic mRNA, BCL2L1, was decreased by $\mathrm{NaB}$ administration and then partially recovered. However, in $I D 2$ knockdown cells, $B C L 2 L 1$ levels did not recover from $\mathrm{NaB}$-induced suppression. ID2 affected the susceptibility of two HCC-derived cell lines to an HDAC inhibitor by regulating the expression of anti-apoptotic genes. Therefore, HDAC inhibitors may be effective for the treatment of HCC for which the prognosis is poor based on $I D 2$ downregulation and $I D 2$ could serve as
\end{abstract}

Correspondence to: Professor Masaaki Oka, Department of Digestive Surgery and Surgical Oncology, Yamaguchi University Graduate School of Medicine, 1-1-1 Minami-Kogushi, Ube, Yamaguchi 755-8505, Japan

E-mail: 2geka-1@po.cc.yamaguchi-u.ac.jp

Key words: inhibitor of DNA binding 2, hepatocellular carcinoma, histone deacethylase inhibitor, apoptosis a marker that is predictive of the clinical response to HDAC inhibitors.

\section{Introduction}

Hepatocellular carcinoma (HCC) is one of the most lethal malignancies worldwide $(1,2)$. HCC is caused mainly by chronic liver inflammation due to hepatitis B virus, hepatitis $\mathrm{C}$ virus (HCV) or alcohol abuse (1). Despite curative resection and recent advances in treatments, the clinical course of HCC is variable and many patients suffer recurrence after surgery. Poor prognoses in cases of HCC can be explained largely by the high rate of intrahepatic recurrence (IHR), which results from metastatic spread of cancer cells (3).

Previously, we identified a gene, inhibitor of DNA binding 2 (ID2), that is significantly downregulated in HCCs, especially in advanced HCCs, relative to surrounding liver tissues $(4,5)$. Moreover, we found that $I D 2$ is a portal vein invasion-related gene in HCV-related HCC (6) and that ID2 negatively regulates the invasive potential of cancer cells (7). Therefore, $\mathrm{HCC}$ patients with low ID2 expression have poor prognoses (7). ID2 belongs to a protein family that comprises ID1 to ID4; these proteins have a helix-loop-helix structure and form heterodimers with basic helix-loop-helix transcription factors to act as dominant-negative inhibitors of transcription (8-10). IDs are involved in proliferation processes, differentiation, development, senescence and angiogenesis (11-15), and are linked to various malignant tumors (16-31).

In this study, we searched for antitumor drugs that are effective against cells with low ID2 expression because such antitumor drugs might be useful in the treatment of patients who have $\mathrm{HCC}$ and a poor prognosis. We found that alteration of $I D 2$ expression affected the susceptibility of cells to histone deacetylase (HDAC) inhibitors and that HDAC inhibitors were the only antitumor drugs tested for which alteration of ID2 expression had an effect. HDAC inhibitors have emerged as a new class of antitumor agents (32-34). HDAC inhibitors can cause multiple epigenetic changes in aberrant cells. Treatment with HDAC inhibitors most frequently induces apoptosis (35-37). Although their precise mode of action remains uncertain, HDAC inhibitors can modulate the cell cycle, apoptosis, angiogenesis, invasion and metastases $(32,33,38-40)$. Here, we aimed to investigate how and whether ID2 affected the antitumor activity of sodium butyrate $(\mathrm{NaB})$, an HDAC inhibitor. 


\section{Materials and methods}

Hepatoma cell lines. Human hepatoma-derived cell lines, HLE and HuH-7, were purchased from the Health Science Research Resources Bank (Osaka, Japan). Cells were cultured in DMEM (Nissui Pharmaceutical, Tokyo, Japan) containing 10\% heat-inactivated fetal bovine serum (Life Technologies, Tokyo, Japan) and supplemented with penicillin $(100 \mathrm{U} / \mathrm{ml})$, streptomycin $(100 \mu \mathrm{g} / \mathrm{ml})$ and sodium bicarbonate $(1.5 \mathrm{~g} / \mathrm{l})$ at $37^{\circ} \mathrm{C}$ in $5 \% \mathrm{CO}_{2}$ in air. As in our previous report (7), ID2-knockdown and ID2-overexpression were accomplished by transfection of HuH-7 and HLE cells with ID2-specific small interfering RNAs (siRNAs) or an ID2-expression plasmid vector, respectively. HuH-7 and HLE cells transfected with control siRNA or empty pcDNA3.1(-) plasmid DNA were used as the respective control.

Administration of histone deacetylase inhibitors. $\mathrm{NaB}$ (Sigma-Aldrich, Tokyo,Japan), sodium4-phenyl-butyrate (NaPB; Funakoshi, Tokyo, Japan), tricostatin A (TSA; Sigma-Aldrich), suberoylanilide hydroxamic acid (SAHA; Cosmo Bio, Tokyo, Japan), MS-275 (Sigma-Aldrich), apicidin (Sigma-Aldrich) and HC-toxin (Sigma-Aldrich) were each used as an HDAC inhibitor in this study. HDAC inhibitors were added to cultures $24 \mathrm{~h}$ after cells had been seeded; cultures were then further incubated with the inhibitor for defined periods at $37^{\circ} \mathrm{C}$ in $5 \% \mathrm{CO}_{2}$ in air.

MTS assay. The CellTiter 96 AQueous One Solution Cell Proliferation Assay (Promega, Tokyo, Japan) which includes 3-(4,5-dimethylthiazol-2-yl)-5-(3-carboxymethoxyphenyl)-2-(4sulfophenyl)-2H-tetrazolium, inner salt (MTS) was used according to the manufacturer's instructions to evaluate cell survival. Cells $\left(3 \times 10^{3}\right)$ were seeded into the wells of 96-well plates and cultivated. At the appropriate time, MTS was added to the cells, which were then incubated for 2 additional hours at $37^{\circ} \mathrm{C}$. The optical density of the culture medium at 492 and $650 \mathrm{~nm}$ were then measured by using an EnVision plate reader (PerkinElmer, Waltham, MA). Triplicate wells were analyzed in each assay.

Annexin Vstaining. The Annexin V-FLUOS Staining Kit (Roche Diagnostics, Tokyo, Japan), which includes Annexin V/propidium iodide (PI), was used according to the manufacturer's instructions to detect apoptosis. The cultures were observed under a fluorescent microscope (IX71; Olympus, Tokyo, Japan). Simultaneously, Hoechst33342-positive cells were counted as total number of cells in cultures; Hoechst33342 was purchased from Sigma-Aldrich.

Semiquantitative real-time RT-PCR. Semiquantitative real-time RT-PCR (semi-qRT-PCR) was performed as described previously $(7,41)$ with minor modifications. Real-time PCR amplification was performed using the LightCycler 480 Probe Master and Universal ProbeLibrary Probes in a LightCycler System Version 3 (all from Roche Diagnostics). Primers and probes that were used are listed in Table I. Amplification was performed according to a two-step cycle procedure consisting of 45 cycles of denaturation at $95^{\circ} \mathrm{C}$ for $10 \mathrm{sec}$ and annealing/elongation at $60^{\circ} \mathrm{C}$ for $30 \mathrm{sec}$. We used the $\Delta / \Delta$ threshold cycle method to semiquantitatively measure mRNA levels; glyceraldehyde-3-phosphate dehydrogenase (GAPDH) and $\beta$-actin
Table I. The primers and hydrolysis probes used in this study.

Primers and probes $\quad$ Sequence $\left(5^{\prime} \rightarrow 3^{\prime}\right)$

ID2

5'-primer

3'-primer

ATATCAGCATCCTGTCCTTGC

Hydrolysis probe UPL Probe $\# 5^{\text {a }}$

$B C L 2$

5'-primer

3'-primer

Hydrolysis probe

TTGACAGAGGATCATGCTGTACTT

ATCTTTATTTCATGAGGCACGTT

$B C L 2 L 1(B C L-X L)$

5'-primer

3'-primer

GCTGAGTTACCGGCATCC

Hydrolysis probe UPL Probe \#83

$B A X$

5'-primer

3'-primer

ATGTTTTCTGACGGCAACTTC

Hydrolysis probe

ATCAGTTCCGGCACCTTG

CDKNIA (P2I)

5'-primer

3'-primer

Hydrolysis probe

GAPDH

5'-primer

UPL Probe $\# 57^{\mathrm{a}}$

3'-primer

Hydrolysis probe

TCACTGTCTTGTACCCTTGTGC

GGCGTTTGGAGTGGTAGAAA

UPL Probe \#32

ACTB

$\begin{array}{ll}\text { 5'-primer } & \text { CCAACCGCGAGAAGATGA } \\ \text { 3'-primer } & \text { CCAGAGGCGTACAGGGATAG } \\ \text { Hydrolysis probe } & \text { UPL Probe \#64 }\end{array}$

${ }^{a}$ The number of Universal ProbeLibrary probes (Roche Applied Bioscience).

$(A C T B)$ were both used as reference genes. All values of mRNA levels are expressed relative to control.

Statistical analysis. Data are presented as mean \pm standard deviation. Dunnett's test for multiple comparisons was used to evaluate the differences between three groups. Calculations were performed using SPSS Statics 17.0 software (IBM, Tokyo, Japan). $\mathrm{P}<0.05$ was considered statistically significant.

\section{Results}

Susceptibility to histone deacetylase inhibitors in HCC-derived cell lines in which ID2 was knocked down or overexpressed. We used the MTS assay and previously established HCC-derived cell lines in which ID2 expression was suppressed or enhanced (7) to examine the susceptibility of HCC cells to antitumor drugs. Among the tested antitumor drugs, the antitumor activity of an HDAC inhibitor, $\mathrm{NaB}$, was increased in $I D 2$ knockdown cells and decreased in ID2-overexpressing cells (Fig. 1). Similar results were obtained with other HDAC inhibitors including TSA, SAHA, PBA, MS-275, apicidin and HC-toxin (Figs. 2 
A ID2 knockdown

$\mathrm{HuH}-7 /$ siCont $\mathrm{O} \mathrm{HuH}-7 /$ silD2-I

$\mathrm{HuH}-7 /$ silD2-II

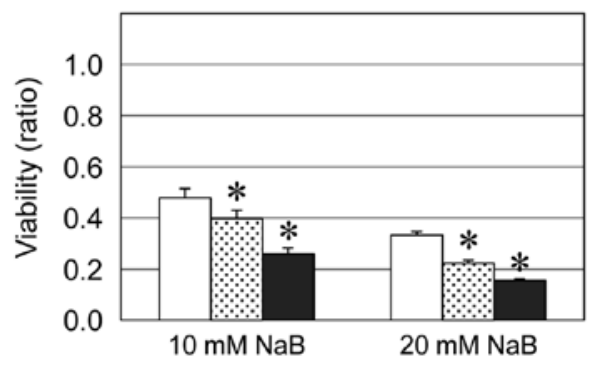

B ID2 overexpression

HLE/pCont

7 HLE/PID2-I

罗 HLE/pID2-II

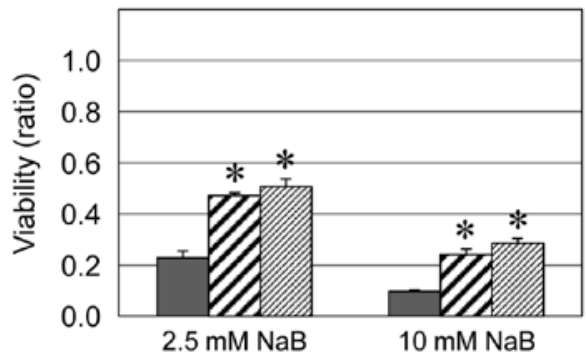

Figure 1. ID2 levels and antitumor activity of NaB. Cells were subjected to an MTS assay $72 \mathrm{~h}$ after $20 \mathrm{mM} \mathrm{NaB}$ administration; NaB is one of several HDAC inhibitors that had an effect on survival of HCC-derived cells. Cell viability was lower in HCC-derived cells transfected with $I D 2$ knockdown siRNAs than those transfected with control siRNA. Cell viability was higher in HCC-derived cells that overexpressed ID2 than in those transfected with an empty vector. "P<0.05 compared with HuH-7/siCont or HLE/pCont.

A TSA (hydroxamic acid)

$\square \mathrm{HuH}-7 /$ siCont $\mathrm{HuH}-7 /$ silD2-I

$\mathrm{HuH}-7 /$ silD2-II

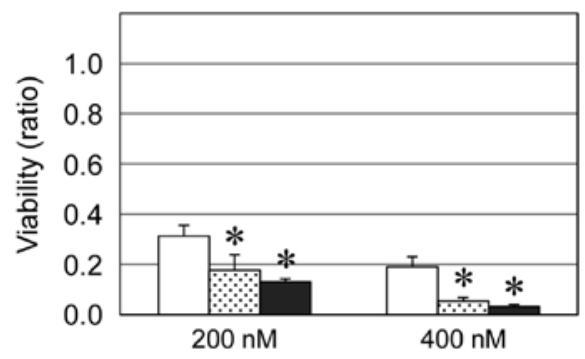

C NaPB (short-chain fatty acid)

$\square \mathrm{HuH}-7 /$ siCont $\mathrm{O} \mathrm{HuH}-7 /$ silD2-I

$\mathrm{HuH}-7 /$ silD2-II

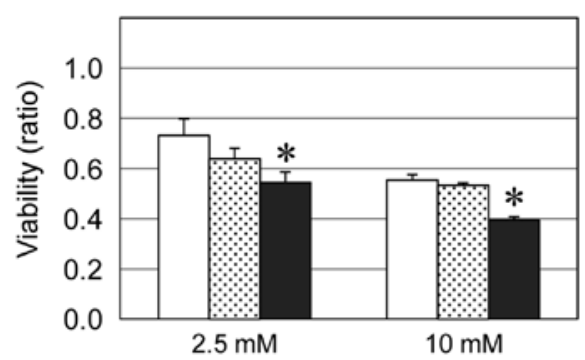

E Apicidin (cyclic peptide)

HuH-7/siCont HuH-7/silD2-I

$\mathrm{HuH}-7 /$ silD2-II

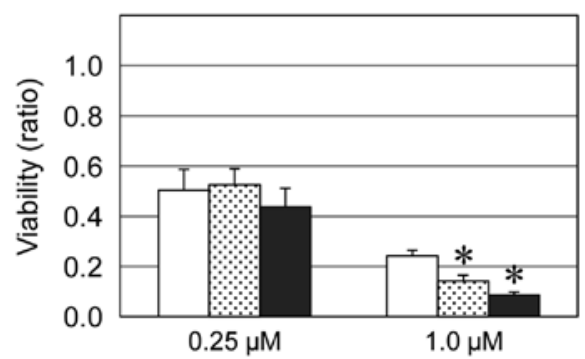

B SAHA (hydroxamic acid)

$\square \mathrm{HuH}-7 /$ siCont $\mathrm{BuH}$-7/silD2-I

$\mathrm{HuH}-7 /$ silD2-II

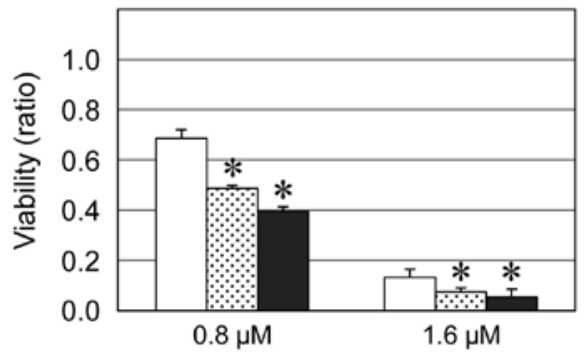

D MS-275 (benzamide)

$\square \mathrm{HuH}-7 /$ siCont $\mathrm{HuH}-7 /$ silD2-I

$\mathrm{HuH}-7 /$ silD2-II

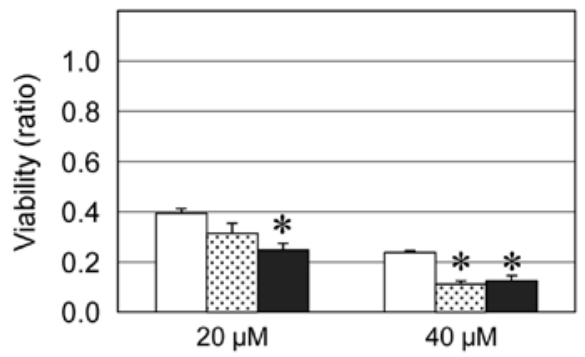

F HC-Toxin (epoxyketone + cyclic peptide) $\square \mathrm{HuH}-7 /$ siCont $\mathrm{BuH}-7 /$ silD2-I

$\mathrm{HuH}-7 /$ silD2-II

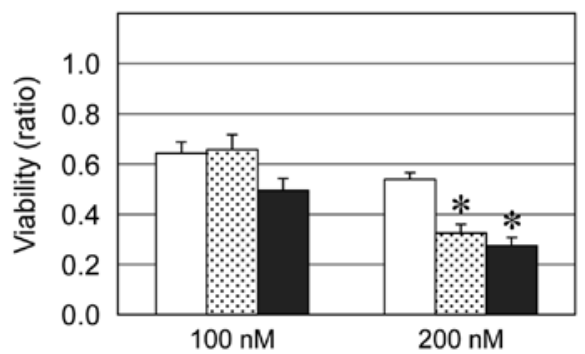

Figure 2. The antitumor activity of HDAC inhibitors in ID2 knockdown cells. Cells were subjected to an MTS assay to evaluate the effect of ID2 on the antitumor activity of HDAC inhibitors other than NaB. Each HDAC inhibitor had an effect similar to that of NaB (Fig. 1) on the ID2 knockdown cells. "P<0.05 compared with HuH-7/siCont. 
A TSA (hydroxamic acid)

$\square$ HLE/pCont

ULE/pID2-I

HLE/pID2-II

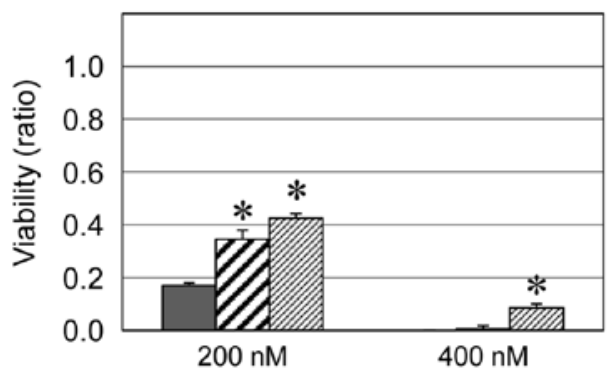

C NaPB (short-chain fatty acid)

$\square$ HLE/pCont $\square$ HLE/pID2-I

HLE/pID2-II

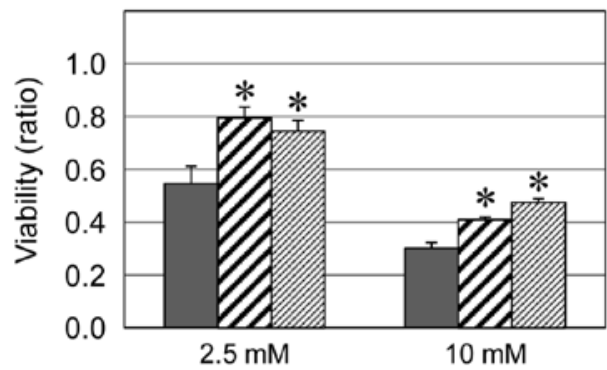

E Apicidin (cyclic peptide)

$\square$ HLE/pCont $\square$ HLE/pID2-I

HLE/pID2-II

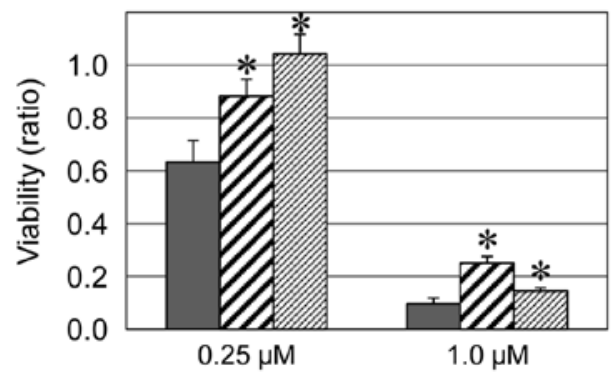

B SAHA (hydroxamic acid)

$\square$ HLE/pCont $\square$ HLE/pID2-I

HLE/pID2-II

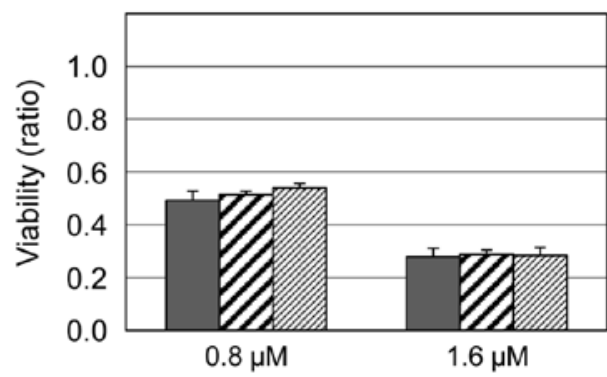

D MS-275 (benzamide)

$\square$ HLE/pCont $\square$ HLE/pID2-I

HLE/pID2-II

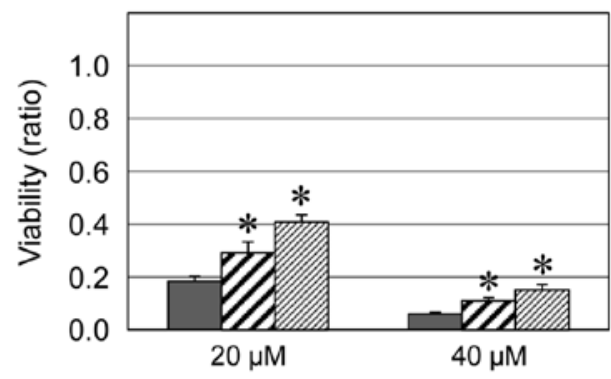

F HC-Toxin (epoxyketone + cyclic peptide)

$\square \mathrm{HLE} / \mathrm{pCont} \square \mathrm{HLE} / \mathrm{pID2}-\mathrm{I}$

HLE/pID2-II

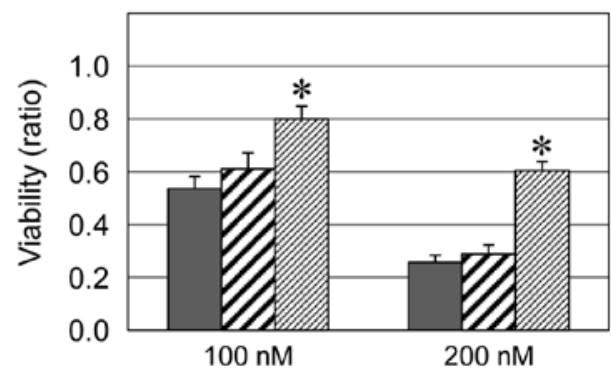

Figure 3. The antitumor activity of HDAC inhibitors in cells that overexpressed ID2. Cells were subjected to an MTS assay to evaluate the effect of ID2 on the antitumor activity of HDAC inhibitors other than NaB. In cells that overexpressed ID2, each HDAC inhibitor, except SAHA, had an effect similar to that of NaB (Fig. 1). ${ }^{*} \mathrm{P}<0.05$ compared with HLE/pCont.

and 3). However, for other types of antitumor agents than HDAC inhibitors (e.g., 5-fluorouracil, cisplatin, docetaxel and etoposide), such results were not observed (Fig. 4).

Influence of ID2 on NaB-induced apoptosis. In HLE derivatives treated with $20 \mathrm{mM} \mathrm{NaB}$ for $72 \mathrm{~h}$, the number of cells positive for both Annexin V and PI (late apoptosis) was significantly lower among ID2-overexpressing cells than empty-vector control cells (approximately 44 vs. 87\%, respectively) (Fig. 5B). For HuH-7 derivatives treated with $20 \mathrm{mM} \mathrm{NaB}$ for $72 \mathrm{~h}$, the percentage of cells positive for both Annexin V and PI (late apoptosis) was 34\% among ID2-knockdown cells and $25 \%$ among siRNA-transfected control cells (Fig. 5A). In both HLE and HuH-7 derivatives,
Annexin V single-positive cells (early apoptosis) showed same tendency with the Annexin V and PI double-positive cells, although Annexin V single-positive cells were less than $10 \%$ of each cell type.

We examined expression of apoptosis-related genes in HLE and HuH-7 cells that had been treated with $\mathrm{NaB}$. Following addition of $20 \mathrm{mM} \mathrm{NaB}$, about half of the HLE cells had died within $24 \mathrm{~h}$ and about half of the HuH-7 cells had died within $48 \mathrm{~h}$. Treatment with $\mathrm{NaB}$ induce expression of BCL2 mRNA (an anti-apoptotic mRNA) in HuH-7 cells transfected with control siRNA and in HLE cells transfected with empty vector; however, this NaB-dependent induction was suppressed in HuH-7 cells transfected with ID2-specific siRNAs and enhanced in HLE cells that overexpressed ID2 
A 5-Fluorouracil

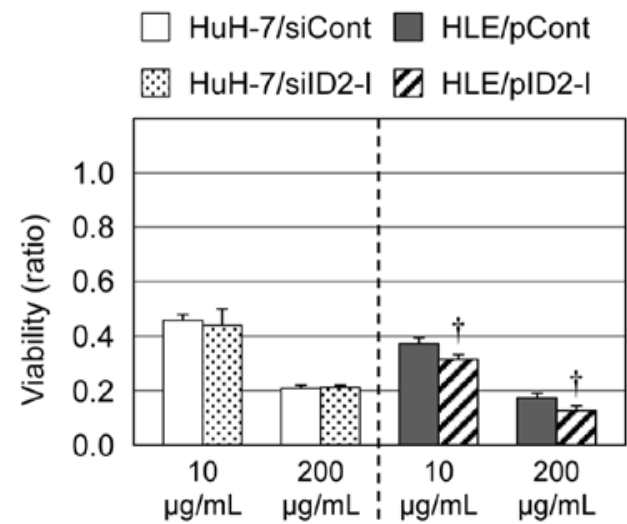

\section{Docetaxel}

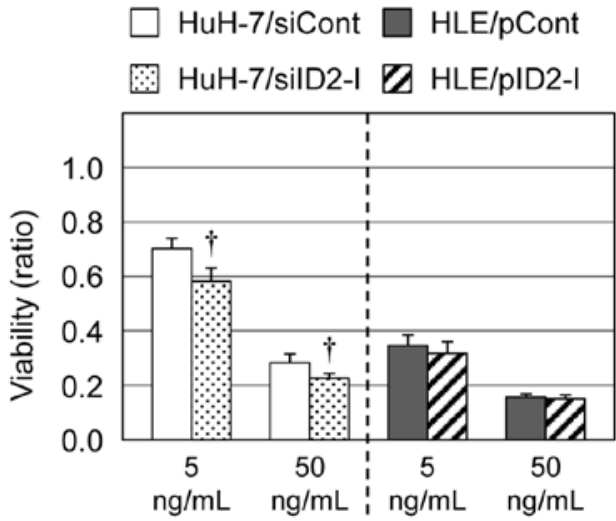

\section{B Cisplatin}
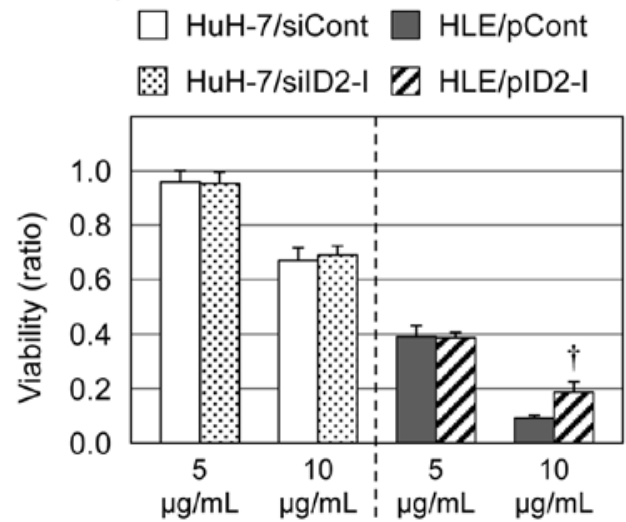

D Etoposide

\section{$\square \mathrm{HuH}-7 /$ siCont $\square \mathrm{HLE} / \mathrm{pCont}$ \\ HuH-7/silD2-I Q HLE/pID2-I}

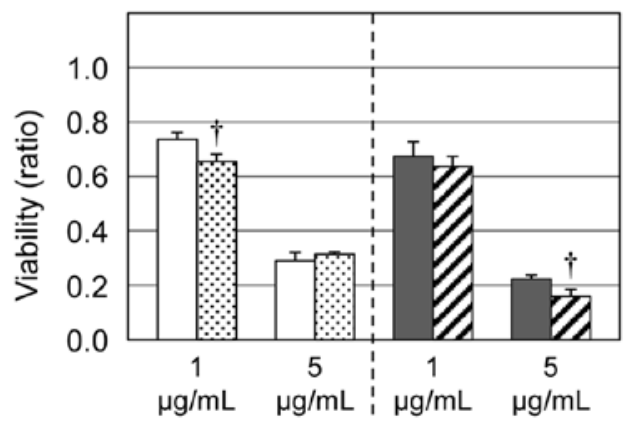

Figure 4. ID2 levels and antitumor activity. Cells were subjected to MTS assay $72 \mathrm{~h}$ after administration of the indicated antitumor drugs,. ${ }^{\dagger} \mathrm{P}<0.05$ compared with HuH-7/siCont or HLE/pCont.

A ID2 knockdown

$\mathrm{HuH}-7 /$ siCont $\mathrm{HuH}-7 /$ silD2-I

$\mathrm{HuH}-7 /$ silD2-II

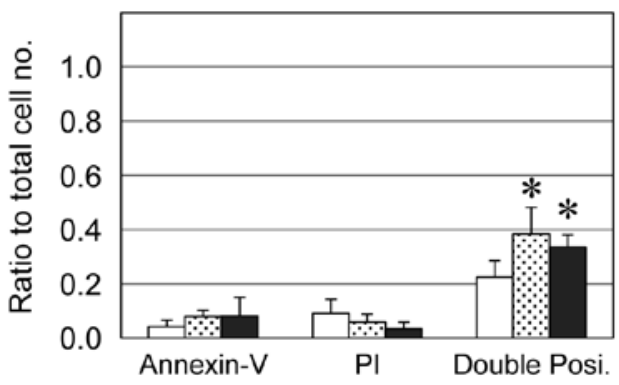

\section{B ID2 overexpression}

HLE/pCont

$\square$ HLE/pID2-I

HLE/pID2-II

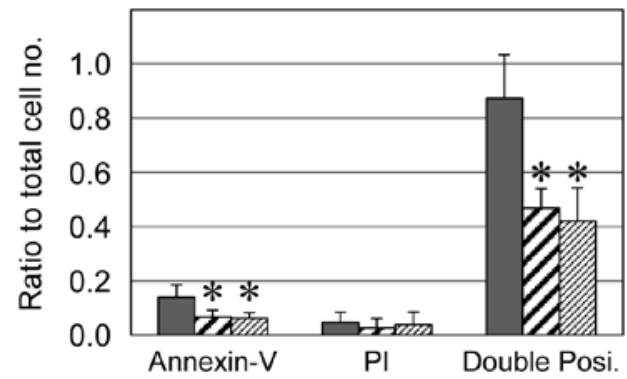

Figure 5. ID2 levels and apoptosis caused by NaB. Cells were stained with Annexin V/Propidium iodide (PI)/Hoechst 33342 after $20 \mathrm{mM} \mathrm{NaB} \mathrm{had} \mathrm{been} \mathrm{admin-}$ istered for $72 \mathrm{~h}$; cells were then assessed by fluorescence microscope. Cells positive for both Annexin V and PI staining were considered to be in the late stage of apoptosis. Cultures containing ID2 knockdown cells had higher percentages of apoptotic cells than did cultures with control siRNA transfected cells. Cultures with $I D 2$ overexpressing cells had lower percentages of apoptotic cells than did cultures containing cells transfected with empty vector. ${ }^{*} \mathrm{P}<0.05$ compared with HuH-7/siCont or HLE/pCont.

(Fig. 6A and B). Levels of another anti-apoptotic mRNA, $B C L 2 L 1$ ( $B C L-X L)$, decreased immediately after addition of $\mathrm{NaB}$ in control HuH-7 cells and in $I D 2$-knockdown HuH-7 cells; $48 \mathrm{~h}$ after $\mathrm{NaB}$ addition, BCL2L1 levels had partially recovered in control cells, but they had not recovered in
ID2-knockdown HuH-7 cells (Fig. 6C). HLE cells that overexpressed ID2 and control HLE cells did not differ significantly in BCL2L1 mRNA levels (Fig. 6D). The mRNA level of $B A X$, a pro-apoptotic gene, was not influenced by ID2 expression (Fig. 6E and F). 

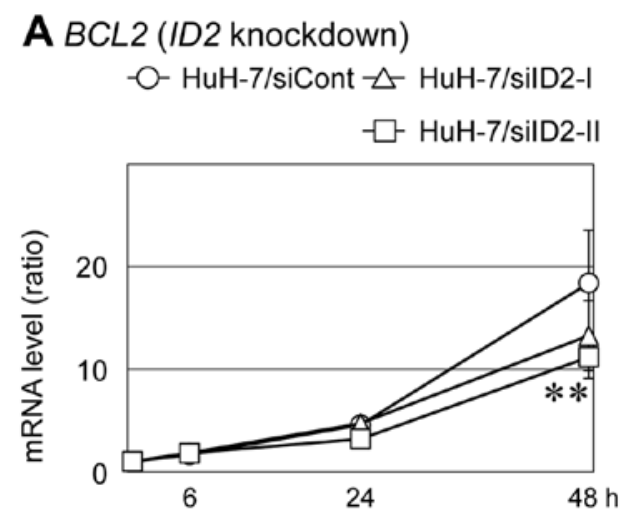

C BCL2L1 (ID2 knockdown)

$-\mathrm{O}-\mathrm{HuH}-7 / \mathrm{siCont}-\triangle \mathrm{HuH}-7 /$ silD2-I

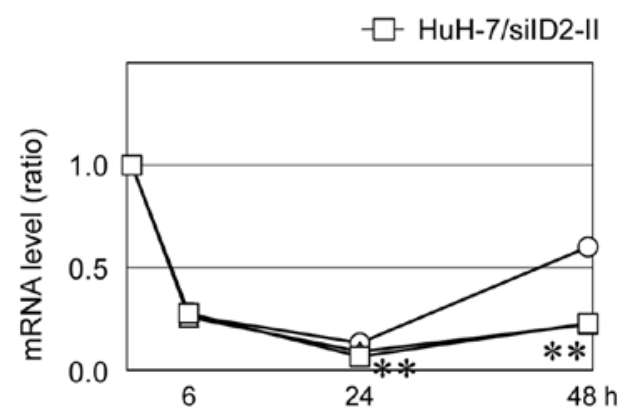

E BAX (ID2 knockdown)

-O- HuH-7/siCont $-\triangle \mathrm{HuH}-7 /$ silD2-I

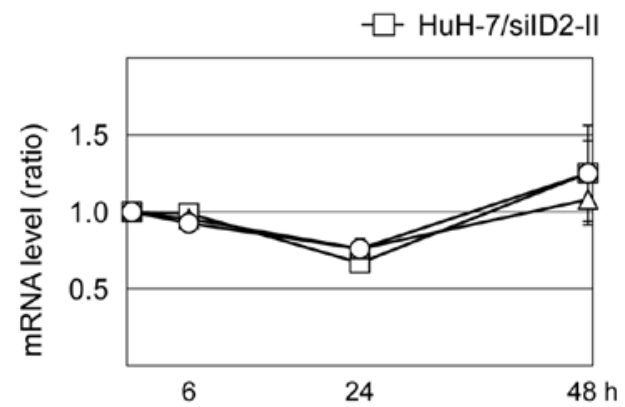

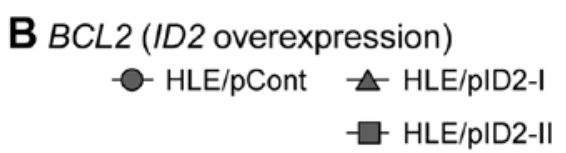
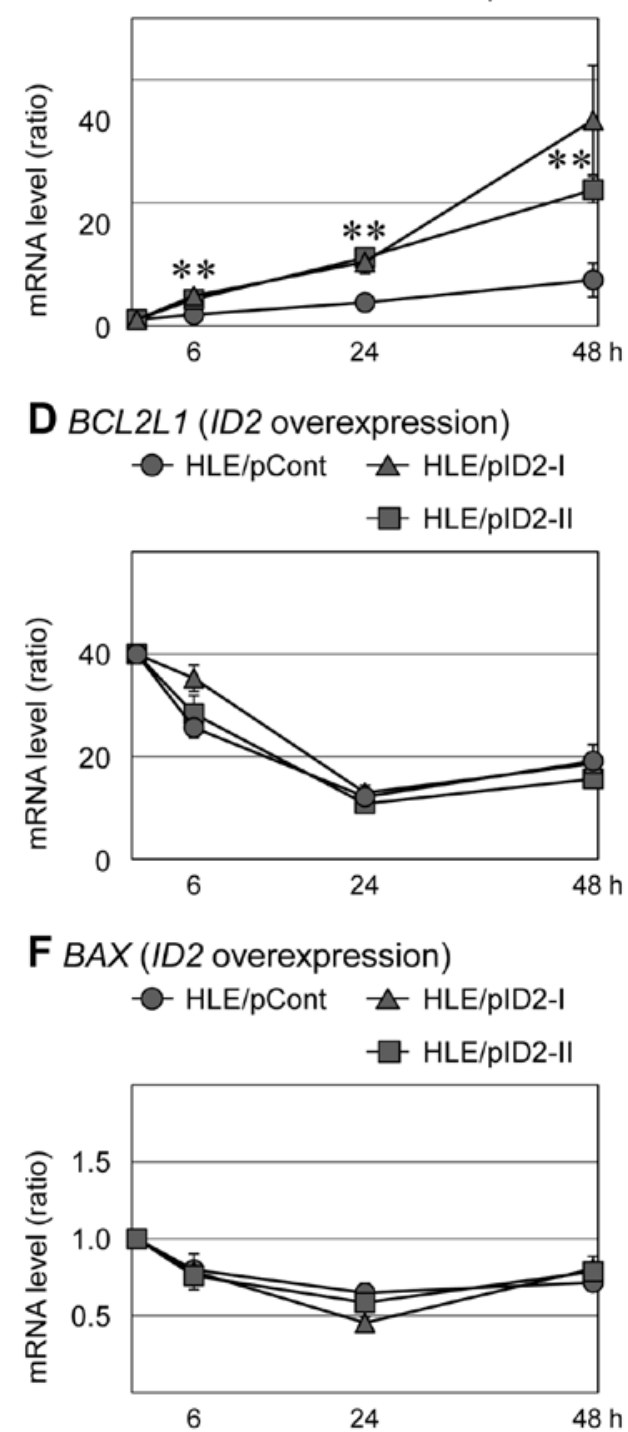

Figure 6. Changes in expression of anti-apoptotic genes following NaB administration. The mRNA levels of BCL2, BCL2L1 and BAX were measured after $20 \mathrm{mM} \mathrm{NaB}$ administration for $0,6,24$ or $48 \mathrm{~h}$. (A and B) BCL2 mRNA level was induced by NaB administration when compared to the induction in control cells, this NaB-dependent induction was suppressed in ID2 knockdown cells and enhanced in cells that overexpressed ID2. (C and D) The BCL2L1 mRNA level decreased immediately after $\mathrm{NaB}$ administration and was then partially restored. In ID2 knockdown cells, the restoration of BCL2L1 expression was largely suppressed relative to that in control cells. ${ }^{* *}$ Both ID2-targeted cells showed $\mathrm{P}<0.05$ compared with control cells.

\section{Discussion}

In this study, ID2 negatively regulated the susceptibility of HCC-derived cells to HDAC inhibitors (Figs. 1-3). Several types of antitumor drugs were tested for their effects on HCC-derived cells with altered ID2 levels; cells became more susceptible HDAC inhibitors when ID2 was downregulated, but no other type of antitumor drug had this effect (Fig. 4). Previous reports showed that $I D 2$ expression was linked to poor prognosis of HCC (5-7). ID2 expression is low in HCC samples that also exhibit other poor prognosis indicators such as poor differentiation or portal vein invasion. Therefore, we reasoned that HDAC inhibitors may be useful for treating $\mathrm{HCC}$ characterized by indicators of poor prognosis.
HDAC inhibitors have emerged as a new class of antitumor drugs that are intended to modulate epigenetic regulation and several clinical trials have been conducted $(42,43)$. Although HDAC inhibitors act on HDACs specifically, genome-wide acetylation of chromatin as a result of HDAC inhibition cause changes in the expression of many genes (45-47). Interestingly, addition of $\mathrm{NaB}$ to $\mathrm{HCC}$-derived cell lines induced expression of anti-apoptotic $B C L 2$ and this induction of $B C L 2$ was positively regulated by $I D 2$ expression (Fig. 6). This finding indicates that $I D 2$ may exert an anti-apoptotic function via regulation of anti-apoptotic genes in the presence of this HDAC inhibitor (Figs. 5 and 6), although a pro-apoptotic gene, $B A X$, was not influenced by $I D 2$ expression (Fig. 6). Cyclin-dependent kinase inhibitor $1 A(C D K N 1 A ; p 21$, Cipl $)$ is 
one of the genes activated by HDAC inhibitors and activated $C D K N 1 A$ inhibits the transition from $\mathrm{G} 1$ to $\mathrm{S}$ phase (48). The activation of $C D K N 1 A$ induced by HDAC inhibitors results in growth arrest and apoptosis in several malignant cell types $(47,49,50)$. We also observed NaB-mediated induction of $C D K N 1 A$ and this induction was significantly suppressed by ID2 overexpression (data not shown). In ID2 knockdown cells, however, that NaB-mediated CDKN1A induction was not affected. The expression of ID2 itself was gradualy induced following the addition of $\mathrm{NaB}$ (data not shown). This increase in ID2 expression might be an endogenous defensive effect in response to HDAC inhibitors. Because ID2 acts as a dominant-negative inhibitor of basic helix-loop-helix transcription factors by forming heterodimers (8-10), some of counter partners forming heterodimers with ID2 may responsible for HDAC susceptibility.

We suggest that ID2 could serve as a predictive marker of the response of $\mathrm{HCC}$ to HDAC inhibitors. ID2 influences the susceptibility of HCC cells to the HDAC inhibitor by regulating the expression of anti-apoptotic genes. Further investigation of the mechanism by which ID2 affects susceptibility to HDAC inhibitors, and of the influence of ID2 on DNA methylation are needed because histone acetylation and DNA methylation are each correlated with epigenetic regulation. Biomarkers for clinical response are strongly needed for improvement of patients' quality of life and also medical economics. ID2 may be useful as a biomarker of the likely response of HCC to HDAC inhibitors; moreover, further research on $I D 2$ expression in HCC may contribute to the identification of new molecular targets that can be altered to enhance the effects of HDAC inhibitors. Such advances may lead to the improvement of antitumor therapy that is based on HDAC inhibitors.

\section{Acknowledgements}

This study was partly supported by JSPS KAKENHI Grant Number 18390366, 24659610, Research Fellowships of the Japan Society for the Promotion of Science for Young Scientists (JSPS KAKENHI Grant Number 187616) and the New Frontier Project of Yamaguchi University School of Medicine.

\section{References}

1. Thorgeirsson SS and Grisham JW: Molecular pathogenesis of human hepatocellular carcinoma. Nat Genet 31: 339-346, 2002.

2. Parkin DM, Bray F, FerlayJ and Pisani P: Global cancer statistics. CA Cancer J Clin 2005 55:74-108, 2002.

3. Bruix J, Boix L, Sala M and Llovet JM: Focus on hepatocellular carcinoma. Cancer Cell 5: 215-219, 2004.

4. Iizuka N, Oka M,Yamada-Okabe H, Mori N, Tamesa T, Okada T, Takemoto N, Sakamoto K, Hamada K, Ishitsuka H, Miyamoto T, Uchimura S and Hamamoto Y: Self-organizingmap-based molecular signature representing the development of hepatocellular carcinoma. FEBS Lett 579: 1089-1100, 2005.

5. Damdinsuren B, Nagano H, Kondo M, Yamamoto H, Hiraoka N, Yamamoto T, Marubashi S, Miyamoto A, Umeshita K, Dono K, Nakamori S, Wakasa K, Sakon M and Monden M: Expression of Id proteins in human hepatocellular carcinoma: relevance to tumor dedifferentiation. Int J Oncol 26: 319-327, 2005.

6. Tsunedomi R, Iizuka N, Yamada-Okabe H, Tamesa T, Okada T, Sakamoto K, Takashima M, Hamaguchi T, Miyamoto T, Uchimura S, Hamamoto Y, Yamada M and Oka M: Identification of ID2 associated with invasion of hepatitis $\mathrm{C}$ virus-related hepatocellular carcinoma by gene expression profile. Int $\mathrm{J}$ Oncol 29: 1445-1451, 2006.
7. Tsunedomi R, Iizuka N, Tamesa T, Sakamoto K, Hamaguchi T, Somura H, Yamada M and Oka M: Decreased ID2 promotes metastatic potentials of hepatocellular carcinoma by altering secretion of vascular endothelial growth factor. Clin Cancer Res 14: 1025-1031, 2008.

8. Benezra R, Davis R, Lockshon D, Turner D and Weintraub H: The protein ID: a negative regulator of helix-loop-helix DNA binding proteins. Cell 61: 49-59, 1990.

9. Kadesch T: Consequences of heteromeric interactions among helix-loop-helix proteins. Cell Growth Differ 4: 49-55, 1993.

10. Norton JD: ID helix-loop-helix proteins in cell growth, differentiation and tumorigenesis. J Cell Sci 113: 3897-3905, 2000.

11. Biggs J, Murphy EV and Israel MA: Id-like helix-loop-helix protein expressed during early development. Proc Natl Acad Sci USA 89: 1512-1516, 1992.

12. Hara E, Yamaguchi T, Nojima H , Ide T, Campisi J, Okayama H and Oda K: Id-related genes encoding helix-loop-helix proteins are required for G1 progression and are repressed in senescent human fibroblasts. J Biol Chem 269: 2139-2145, 1994.

13. Rivera R and Murre C: The regulation and function of the Id proteins inlymphocyte development. Oncogene 20: 8308-8316, 2001.

14. Zebedee $\mathrm{Z}$ and Hara E: Id proteins in cell cycle control and cellular senescence. Oncogene 20: 8317-8325, 2001.

15. Benezra R, Rafii S and Lyden D: The Id proteins and angiogenesis. Oncogene 20: 8334-8341, 2001.

16. Ellmeier W, Aguzzi A, Kleiner E, Kurzbauer R and Weith A: Mutually exclusive expression of a helix-loop-helix gene and $\mathrm{N}$-myc in human neuroblastomas and in normal development. EMBO J 11: 2563-2571, 1992.

17. Israel MA, Hernandez MC, Florio M, Andres-Barquin PJ, Mantani A, Carter JH and Julin CM: Id gene expression as a key mediator of tumor cell biology. Cancer Res 59: 1726s-1730s, 1999.

18. Lyden D, Young AZ, Zagzag D, Yan W, Gerald W, O'Reilly R, Bader BL, Hynes RO, Zhuang Y, Manova K and Benezra R: Id1 and Id 3 are required for neurogenesis, angiogenesis and vascularization of tumour xenografts. Nature 401: 670-677, 1999.

19. Maruyama H, Kleeff J, Wildi S, Friess H, Büchler MW, Israel MA and Korc M: Id-1 and Id-2 are overexpressed in pancreatic cancer and in dysplastic lesions in chronic pancreatitis. AmJ Pathol 155: 815-822, 1999.

20. Lin CQ, Singh J, Murata K, Itahana Y, Parrinello S, Liang SH, Gillett CE, Campisi J and Desprez PY: A role for Id-1 in the aggressive phenotype and steroid hormone response of human breast cancer cells. Cancer Res 60: 1332-1340, 2000.

21. Langlands K, Down GA and Kealey T: Id proteins are dynamically expressed in normal epidermis and dysregulated in squamous cell carcinoma. Cancer Res 60: 5929-5933, 2000.

22. Wilson JW, Deed RW, Inoue T, Balzi M, Becciolini A, Faraoni P, Potten CS and Norton JD: Expression of Id helix-loop-helix proteins in colorectal adenocarcinoma correlates with p53 expression and mitotic index. Cancer Res 61: 8803-8810, 2001.

23. Schindl M, Schoppmann SF, Ströbel T, Heinzl H, Leisser C, Horvat R and Birner P: Level of Id-1protein expression correlates with poor differentiation, enhanced malignant potential and more aggressive clinical behavior of epithelial ovarian tumors. Clin Cancer Res 9: 779-785, 2003.

24. Itahana Y, Singh J, Sumida T, Coppe JP, Parrinello S, Bennington JL and Desprez PY: Role of Id-2 in the maintenance of a differentiated and noninvasive phenotype in breast cancer cells. Cancer Res 63: 7098-7105, 2003

25. Coppe JP, Itahana Y, Moore DH, Bennington JL and Desprez PY: Id-1 and Id-2 proteins as molecular markers for human prostate cancer progression. Clin Cancer Res 10: 2044-2051, 2004.

26. Umetani N, Takeuchi H, Fujimoto A, Shinozaki M, Bilchik AJ and Hoon DS: Epigenetic inactivation of ID4 in colorectal carcinomas correlates with poor differentiation and unfavorable prognosis. Clin Cancer Res 10: 7475-7483, 2004.

27. de Candia P, Benera R and Solit DB: A role for Id proteins in mammary gland physiology and tumorigenesis. Adv Cancer Res 92: 81-94, 2004.

28. Stighall M, Manetopoulos C, Axelson H and Landberg G: High ID2 protein expression correlates with a favourable prognosis in patients with primary breast cancer and reduces cellular invasiveness of breast cancer cells. Int J Cancer 115: 403-411, 2005.

29. Umetani N, Mori T, Koyanagi K, Shinozaki M, Kim J, Giuliano AE and Hoon DS: Aberrant hypermethylation of ID4 gene promoter region increases risk of lymph node metastasis in T1 breast cancer. Oncogene 24: 4721-4727, 2005. 
30. Matsuda Y, Yamagiwa S,Takamura M, Honda Y, Ishimoto Y, Ichida T and Aoyagi Y: Overexpressed Id-1 is associated with a high risk of hepatocellular carcinoma development in patients with cirrhosis without transcriptional repression of p16. Cancer 104: 1037-1044, 2005.

31. Lee TK, Poon RT, Yuen AP, Ling MT, Wang XH, Wong YC, Guan XY, Man K, Tang ZY and Fan ST: Regulation of angiogenesis by Id-1 through hypoxia-inducible factor-1a-mediated vascular endothelial growth factor up-regulation in hepatocellular carcinoma. Clin Cancer Res 12: 6910-6919, 2006.

32. Drummond DC, Noble CO, Kirpotin DB, Guo Z, Scott GK and Benz CC: Clinical development of histone deacetylase inhibitors as anticancer agents. Annu Rev Pharmacol Toxicol 45: 495-528, 2005

33. Liu T, Kuljaca S, Tee A and Marshall GM: Histone deacetylase inhibitors: multifunctional anticancer agents. Cancer Treat Rev 32: 157-165, 2006.

34. Khan $\mathrm{O}$ and La Thangue NB: HDAC inhibitors in cancer biology: Emerging mechanisms and clinical applications. Immunol Cell Biol 90: 85-94, 2012.

35. Rosato RR, Almenara JA, Dai Y and Grant S: Simultaneous activation of the intrinsic and extrinsic pathways by histone deacetylase (HDAC) inhibitors and tumor necrosis factorrelated apoptosis-inducing ligand (TRAIL) synergistically induces mitochondrial damage and apoptosis in human leukemia cells. Mol Cancer Ther 2: 1273-1284, 2003.

36. Emanuele S, Lauricella M and Tesoriere G: Histone deacetylase inhibitors: Apoptotic effects and clinical implications. Int J Oncol 33: 637-646, 2008.

37. Zhang J, Kan S, Huang B, Hao Z, Mak TW and Zhong Q: Mule determines the apoptotic response to HDAC inhibitors by targeted ubiquitination and destruction of HDAC2. Genes Dev 25: 2610-2618, 2011.

38. Vigushin DM and Coombes RC: Histone deacetylase inhibitors in cancer treatment. Anticancer Drugs 13: 1-13, 2002.

39. Lin HY, Chen CS, Lin SP, Weng JR and Chen CS: Targeting histone deacetylase in cancer therapy. Med Res Rev 26: 397-413, 2006

40. Xu WS, Parmigiani RB and Marks PA: Histone deacetylase inhibitors: molecular mechanisms of action. Oncogene 26 : 5541-5552, 2007.
41. Tsunedomi R, Ogawa Y, Iizuka N, Sakamoto K, Tamesa T, Moribe T and Oka M: The assessment of methylated BASP1 and SRD5A2 levels in the detection of early hepatocellular carcinoma. Int J Oncol 36: 205-212, 2010.

42. Kouzarides T: Histone acetylases and deacetylases in cell proliferation. Curr Opin Genet Dev 9: 40-48, 1999.

43. Marks PA, Richon VM and Rifkind RA: Histone deacetylase inhibitors:inducers of differentiation or apotosis of transformed cells. J Natl Cancer Inst 92: 1210-1216, 2000.

44. Timmermann S, Lehrmann H, Polesskaya A and Harel-Bellan A: Histone acetylation and disease. Cell Mol Life Sci 58: 728-736, 2001.

45. Ogawa K, Yasumura S, Atarashi Y, Minemura M, Miyazaki T, Iwamoto M, Higuchi K and Watanabe A: Sodium butyrate enhances Fas-mediated apoptosis of human hepatoma cells. J Hepatol 40: 278-284, 2004.

46. Joseph J, Mudduluru G, Antony S, Vashistha S, Ajitkumar P, and Somasundaram K: Expression profiling of sodium butyrate $(\mathrm{NaB})$-treated cells: identification of regulation of genes related to cytokine signaling and cancer metastasis by $\mathrm{NaB}$. Oncogene 23: 6304-6315, 2004

47. Chiba T, Yokosuka O, Arai M, Tada M, Fukai K, Imazeki F, Kato M, Seki N and Saisho H: Identification of genes up-regulated by histone deacetylase inhibition with cDNA microarray and exploration of epigenetic alterations on hepatoma cells. J Hepatol 41: 436-445, 2004

48. Chen J, Saha P, Kornbluth S, Dynlacht BD and Dutta A: Cyclinbinding motifs are essential for the function of p21CIP1. Mol Cell Biol 16: 4673-4682, 1996.

49. Shin JY, Kim HS, Park J, Park JB and Lee JY: Mechanism for inactivation of the KIP family cyclin-dependent kinase inhibitor genes in gastric cancer cells. Cancer Res 60: 262-265, 2000.

50. Han JW, Ahn SH, Kim YK, Bae GU, Yoon JW, Hong S, Lee HY, Lee YW and Lee HW: Activation of $\mathrm{p} 21^{\mathrm{WAF} 1 / \mathrm{Cipl}}$ transcription through $\mathrm{Sp} 1$ sites by histone deacetylase inhibitor apicidin. J Biol Chem 276: 42084-42090, 2001. 